\title{
Bimbingan dan Konseling Islami dan Problem Mayarakat
}

Oleh: Nadzmi Akbar, S.Pd., M.Pd.I

Abstract

Broadly speaking, the buman problem consists of problems associated with itself, problems relating to others, problems related to the environment and the problem of the relationship with God. The inability of bumans to adapt to the components mentioned above, causes people in trouble.

Islamic Guidance is the process of providing assistance from a mentor (counselor / helper) to a client / helpee. In the implementation of the aid, a mentor / helper should not be overbearing or require client / helpee to follow what he suggested, but merely provide direction, guidance and assistance, and the assistance provided was more focused to belp yag relating to psychiatric / mental and not relating to material or financial directly.

Problems that occur in society in general are: personal problems, social problems, family problems, marital problems, problems of education, health and physical problems, problems of employment and careers, economic problems, problems of religion, relationship problems young couple.

Guidance and counseling is an attempt to avoid and alleviate problems in the community. Guidance and counseling have a function that is a function of prevention, alleviation, understanding, preservation and distribution, and advocacy.

Keywords: Guidance, Counseling, Islamic, Problem

\section{A. Pendahuluan}

Semakin maju peradaban di muka bumi ini, semakin banyak menyajikan kemudahan-kemudahan bagi manusia, apakah keadaan tersebut menyebabkan manusia tanpa problem?. Jawab nya TIDAK justru sebaliknya manusia penuh dengan masalah dalam kehidupannya.

Sejak terjadi perubahan dari masyarakat tradisional ke modern manusia ternyata selalu dihinggapi problem kehidupan. Ketika terjadi revolusi industri sejak itulah banyak orang-orang yang mecari tempat mengadu dan berkeluh kesah dengan problem yang dihadapi.

Realita saat ini banyak sekali bermunculan peristiwa kejadian yang sebenarnya berakar dari problem yang tidak terentaskan. Misalnya bunuh diri, penggunaan dean kecanduan narkoba dan napza, perkosaan, permerasan, kekerasan dalam rumah tangga, kekerasan terhadap anak, bahkan bermunculan pedofil yang merasahkan mayakat. Problem manusia pada peradaban saat ini, sebagaimana gunung es yang terlihat hanya sedikit tetapi yang tidak terlihat masih sangat banyak.

Secara garis besar problem manusia itu terdiri dari problem yang berhubungan dengan dirinya sendiri, problem yang berhubungan dengan orang lain, problem yang berhubungan dengan lingkungan dan problem hubungan dengan tuhan. Ketidak mampuan manusia dalam menyesuaikan diri dengan komponen sebagaimana tersebut di atas menyebabkan manusia tertimpa masalah.

Bimbingan dan konseling yang kegiatan pokoknya membantu manusia yang ditimpa beban masalah pada aspek psikis. Bimbingan dan konseling yang sifatnya sosial membantu dengan ikhlas semua orang yang tanpa memandang status sosial, ekonomi, jabatan dan lain sebagainya. Pada intinya bimbingan dan konseling sebenarnya sangat diperlukan karena masyarakat sekarang ini penuh dengan problem kehidupan.

\section{B. Bimbingan dan Konseling Islami}


Pada sub judul tersebut di atas terdapat tiga kata yaitu bimbingan, konseling dan Islami. Dalam kamus pendidikan (Dictionary of Education, 1973) bimbingan adalah suatu proses membantu seseorang untuk memahami dirinya dan dunianya.

Bimbingan adalah proses pemberian bantuanyang dilakukan oleh orang yang ahli kepada seorang atau beberapa orang individu, baik anak-anak, remaja, maupun dewasa; agar orang yang dibimbing dapat mengembangkan kemampuan dirinya sendiri dan mandiri; dengan memanfaatkan kekuatan individu dan sarana yang ada dan dapat dikembangkan; berdasarkannorma-norma yang berlaku. ( Prayitno 2004 : 99). Kemandirian yang dimaksud di atas mencakup lima hal, yaitu :

a. Mengenal diri sendiri dan lingkungannya

b. Menerima diri sendiri dan linkungannya secara positif dan dinamis

c. Mengambil keputusan

d. Mengarahkan diri

e. Mewujudkan diri

Konseling secara singkat bisa dikatakan sebagai pemberian nasehat, penujuk jalan.

Sehubungan Bimbingan Islami, Tohari Musnamar (1992 : 5), mendefinisikan bimbingan islami adalah proses pemberian bantuan terhadap individu agar mampu hidup selaras sesuai dengan ketentuan dan petunjuk Allah, sehingga dapat mencapai kebahagiaan hidup di dunia dan di akhirat.

Berdasarkan definisi ini, bimbingan islami merupakan proses bimbingan sebagaimana proses bimbingan lainnya, tetapi dalam segala aspek kegiatannya selalu berlandaskan ajaran Islam yaitu sesuai dengan prinsip - prinsip Alqur'an dan sunnah Nabi Muhammad SAW.

Bimbingan Islami adalah usaha bantuan yang sitematis dan kontenu yang diberikan oleh pembimbing kepada individu atau kelompok individu, agar mencapai kebahagiaan hidup di dunia dan akhirat dengan cara peningkatan pengetahuan diri (self knowledge), kesediaan menerima diri sendiri (self acceptance), kepercayaan diri (self confidence), kedisiplinan (self diciplener), dengan petunjuk-petunjuk yang islami sehingga dengan demikian individu/kelompok individu dapat menentukan tindakan yang tepat dalam kehidupan di dunia sesuai dengan petunjuk Al Qur'an dan Hadist.

Bimbingan Islami merupakan proses pemberian bantuan dari seorang pembimbing (konselor/helper) kepada klien/helpee. Dalam pelaksanaan pemberian bantuan, seorang pembimbing/helper tidak boleh memaksakan kehendak atau mewajibkan klien/helpee untuk mengikuti apa yang disarankannya, melainkan sekedar memberi arahan, bimbingan dan bantuan, dan bantuan yang diberikan itu lebih terfokus kepada bantuan yag berkaitan dengan kejiwaan/mental dan bukan yang berkaitan dengan material atau finansial secara langsung.

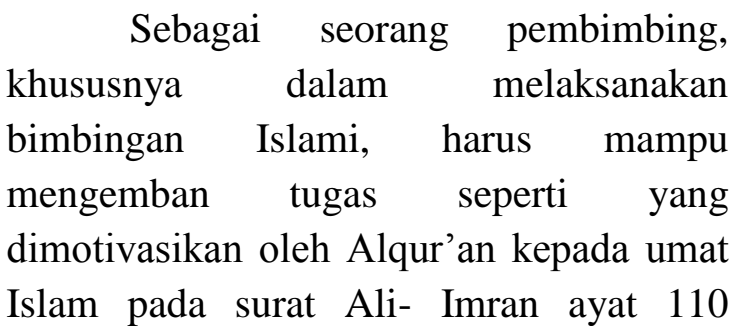


kepada kliennya, yaitu : Artinya : Kamu adalah umat yang terbaik yang dilahirkan untuk manusia, menyuruh kepada yang ma'ruf, dan mencegah dari yang munkar, dan beriman kepada Allah......(Q.S. 3 :110).

Berdasarkan ayat ini, paling tidak terdapat tiga tugas setiap orang Islam, khususnya konselor Islami kepada umat Islam atau kliennya, yaitu :

Tugas umat islam pada bahagian ini, khususnya konselor Islami adalah memberi kesadaran kepada klien agar mereka selalu tunduk dan patuh kepada ajaran Allah SWT, dan dapat menyadari bahwa tidak seorangpun dari manusia ini yang bisa berhasil tanpa hidayah dan ma'unah Allah.

Konseling adalah salah satu teknik dari bimbinganyang terfokus pada usaha usaha pembimbing terhadap individu (klien) yang mempunyai problem hidup, dengan cara wawancara, di dalamnya terjadi proses peningkatan pemahaman diri, pemahaman terhadap problem diri dengan meneliti kekeliruan prilaku psikis dan psikomotor, dengan demikian individu (klien) akan mempunyai konsep diri yang tepat dalam menghadapi problem hidup.

Konseling islami adalah usaha bantuan terhadap individu yang dilakukan oleh konselor Islam terhadap individu yang beragama Islam dalam menghadapi berbagai problem kehidupan dari berbagai aspek, dengan memahami diri sendiri, orang lain dan lingkungannya dibarengi dengan upaya peningkatan keyakinan dan keimanan terhadap Allah SWT, dengan berpegang kepada Alqura dan hadist.

\section{Problem Kehidupan}

Setiap bidang dan aspek kehidupan manuia rentan terjadinya problem kehidupan, yang secara singkat problem adalah kenyataan tidak sesuai harapan. Aspek problrm manusia itu antara lain :

1. Problem Pribadi

Problem pribadi ini menyagkut masalah pribadi yang berasal dari dalam diri individu yang bersangkutan artinya potensi masalah datang dari diri individu itu sendiri.

Misalnya rendah diri, stabilitas emosi, cara pandang, karakter diri dan kebiasaan, potensi dan kelemahan yang dimiliki individu yang sedikit sekali dipengaruhi oleh faktor luar. Problem pribadi lebih muncul karena factor intrn individu.

2. Problem Sosial

Problem sosial ini menyangkut ketidak mampuan adaptasi individu dengan orang lain terutama dengan teman sebayanya, sehingga orang lain kadar penghargaan dan perhatian orang lain sangat pada diri inidividu bersangkutan. Problem sosial ini juga menyangkut peran orang lain dalam mempengaruhi populer dan terisolernya seseorang.

3. Problem Pendidikan

Problem pendidikan ini terutama sekali pada aspek jurusan dan lembaga pendidikan yang dijalani dan yang akan dijalani. Pendidikan juga mengenai tentang pendidikan formal, non formal dan informal.

Pada umumnya ada dua hal yang data menyebabkan terjadinya problem pendidikan ini yaitu ; pertama sempitnya pengetahuan individu tentang jurusan, lembaga pendidikan yang dapat ditempuhnya, kedua 
pendidikan yang dijalani tidak sesuai dengan potensi individu bersangkutan.

4. Problem Keluarga

Problem keluarga ini menyangkut masalah hubungan antar anggota keluarga, misalnya hubungan ayah dengan anak, anak dengan ibu, mertua dengan menantu. Ketidak harmonisan hubungan dalam keluarga itulah akar persoalan sesungguhnya dalam problem keluarga.

5. Problem Perkawinan

Problem ini berhubungan dengan masalah-masalah perkawinan antara lain : kawin paksa, perkawinan yang tidak direstui orangtua, cemburu, perselingkuhan, suami kawin lagi.

Selain itu juga aspek kematangan emosi juga punya andil besar terhadap problem perkawinan misalnya bosan, pemarah, berkurang rasa cinta dan kasih sayang, perasaan mudah tersinggung.

6. Problem Keadaan Fisik dan Kesehatan Problem fisik dan kesehatan ini menyangkut keadaan fisik yang tidak sempurna, sehingga menjadi sesuatu yang menganggu pada aspek kegiatan sehari-hari maupun pada aspek kepercayaan diri individu.

Keadaan kesehatan yang dapat menganggu pada aspe menjalankan hidup sehari-hari juga akan berhubungan dengan semangat hidup, apalagi keadaan kesehatan yang akut sekian lama di derita tidak sembuhsembuh akan menganggu pada aspek kehidupan psikis individu.

7. Problem Pekerjaan dan Karir

Problem pekerjaan menyangkut terbatasnya lowongan pekerjaan sehingga terjadi pengangguran.
Pengangguran akan menjadi beban mental yang cukup berat bagi individu dan menjadi beban keluarga ataupun orang lain, dengan demikian ha terebut menjadi masalah yang cukup serius di masyarakat.

Problem karir dapat menimpa orang yang sudah bekerja, dalam bekerja akan terjadi persaingan-persaingan baik sesama rekan kerja maupun yang bukan rekan kerja sehingga karir individu tidak berkembang, kesalahan penempatan juga akan menjadi problem bagi individu dalam menjalankan pekerjaannya setiap hari.

8. Problem Agama

Problem ini menyangkut ketidak mampuan dalam menjalankan ajaranajaran agama, dan juga menyangkut keyakinan seseorang teradap agama yang dianutnya.

9. Problem Ekonomi

Himpitan ekonomi yang terhadap seseorang akan menjadi problem yang serius dan akan menyebar dan menyemai tumbuhnya masalah-masaah baru. Kemiskinan mendekati kekufuran, tentunya problem ekonomi ini harus juga diselesaikan bagi individu bersangkutan.

Pada sisi lain harta yang berlimpah ternyata jug mendatangkan masalah baru, harta digunakan untuk poyapoya, anak dimanja dengan segala kemudahan dan serba ada yang pada akhirnya anak tidak dapat hidup mandiri.

10. Problem Hubungan Muda Mudi

Pada masa-masa tertentu setiap manusia akan merasakan jatuh cinta, yang pada gilirannya akan mendatangkan berbagai gejolak 
perasaan yang terkadang sangat mengganggu prkembangan psikis.

Problem-problem hubungan mudamudi antara lain : putus cinta, cinta bertepuk sebelah tangan, mabuk cinta dan lain sebagainya.

\section{Panyuluh dan Fungsinya di Masyarakat}

Penyuluh sebagai pengemban tugas menjalankan proses bimbingan dan konseling mempunyai tanggung jawab dan kewajiban membantu masyarakat dalam menghadapi problem kehidupan.

Kegiatan bimbingan dan konseling berfungsi mencegah, mengentaskan, menyalurkan, pemahaman dan pemeliharaan sehubungan dengan problem-problem kehidupan di masayarakat. Dilihat dari fungsinya pelaksanaan bimbingan dan konseling di tengah problem masyarakat akan membuat kehidupan masyarakat berjalan harmonis dalam situasi kondusif dan perkembangan aspek psikis secara optimal.

\section{Fungsi Preventif/ Pencegahan}

Pelaksanaan bimbingan dan koseling dengan menggunakan berbagai metode dan pendekatannya di masyarakat akan berfungsi mecegah terjadinya problem atau masalah bagi individu.

Dalam hal ini penyuluh harus jeli melihat fenomena kehidupan di masyarakat, penyuluh harus mengedentifikasi gejala kehidupan di masyarakat yang kemungkinan besar individu tertimpa masalah tertentu.

Materi bimbingan harus menyesuaikan gejala-gejala kemungkinan problem akan terjadi pada individu di suatu lingkungan masayarakat. Sehingga tujuan, materi dan pelaksanaan bimbingan sesuai dengan kebutuhan individu di masyarakat.

2. Fungsi Pengentasan

Bagi individu yang sudah tertimpa masalah bantuan yang diberikan penyuluh adalah pelaksanaan konseling, baik konseling individual maupun kelompok. Proses konseling ini terjadi dimulai dengan datangnya individu secara sukarela, ataupun dengan dipanggil atau dikunjungi.

Pelaksanaan konseling kelompok bisa terjadi, karena beberapa individu memiliki berbagai kesamaan atau homogen misalnya; dari segi masalahnya, usia, jenis kelamin dan terutama agamanya.

Proses konseling dilaksanakan dimulai dari analisis, sintesis, diagnosis, konseling (treatment), dan follow-up. Langkah-langkah tersebut menjadikan proses konseling berjalan efektif dan terentaskannya masalah yang dihadapi individu.

\section{Fungsi Pemahaman}

Bimbingan dan konseling juga memiliki fungsi pemahaman, artinya proses bimbingan dan konseling berupaya membangun pemahaman bagi diri individu. Hal-hal yang peru dipahami yaitu diri sendiri, orang lain, keluarga dan masyarakat, serta lingkungan.

Dengan pemahaman terhadap berbagai hal tersebut akan berakibat pada tumbuhnya kemampuan individu untuk menyesuaikan diri dengan baik terhadap keadaan dirinya, orang lain dan lingkungan. Dengan kemampuan penyesuaian diri yang baik akan menghindarkan individu dari berbagai penomena dan problem kehidupan 
yang selalu ada ditengah-tengah masyarakat.

4. Fungsi Penyaluran

Tersumbatnya keinginan, bakat, minat, hobi seseorang untuk merealisasikan diri akan berdampak pada munculnya problem kehidupan.

Kegiatan bimbingan dan konseling melayani upaya-upaya penyaluran individu baik menyalurkan pada aspek pendidikan maupun dalam hal menentukan bidang pekerjaan yang sesuai dengan potensinya.

5. Fungsi Advokasi

Fungsi ini adalah upaya-upaya pembelaan dan perlindungan terhadap individu dalam mengembangkan dirinya, secara optimal.Dengan keilmuan, skill, kewenangan, dan kode etik yang dimiliki penyuluh, semua fungsi-fungsi sebagaimana tersebut di atas, keberadaan penyuluh akan membawa masyarakat yang tentaram bahagia dalam hidupnya dan bahagia di akhirat.

\section{E. Simpulan}

Selama manusia ada di muka bumi ini, maka problem kehidupanpun selalu ada di dunia. Agar problem tersebut tidak menjadi beban berat bagi manusia, problem tersebut harus dihindari, jika memang sudah menimpa individu masalah tersebut harus dientaskan.

Bimbingan dan konseling adalah usaha untuk menghindari dan mengentaskan problem di masyarakat. Bimbingan dan konseling memiliki fungsifungsi yaitu fungsi pencegahan, pengentasan, pemahaman, pemeliharaan dan penyaluran serta advokasi.

Penyuluh dalah pelaksana kegiatan bimbingan dan konseling yang tentunya juga melaksanakan fungsi-fungsi sebagaimana tersebut di atas. Seorang penyuluh harus memiliki keilmuan, skill, kewinangan, dan aturan atau kode etik pada bidang bimbingan dan konseling.

\section{Daftar Pustaka}

M. Arifin, 1985, Pokok-pokok Pikiran Tentang Bimbingan dan Penyuluhan Agama, Bulan Bintang, Jakarta.

Hallen A., 2002, Bimbingan dan Konseling dalam Islam, Ciputat press, Jakarta

Hamdan Bakhran adz Dzaky, 2001, Psikoterapi dan Konseling Islam, Fajar Pustaka Baru, Yokyakarta.

Prayitno dan Erman Amti, 2004, Dasar-dasar Bimbingan dan Konseling, Rineka Cipta, Jakarta.

Tohari Musnamar, 1994, Bimbingan Penyuluhan Agama, Bulan Bintang, Jakarta. 